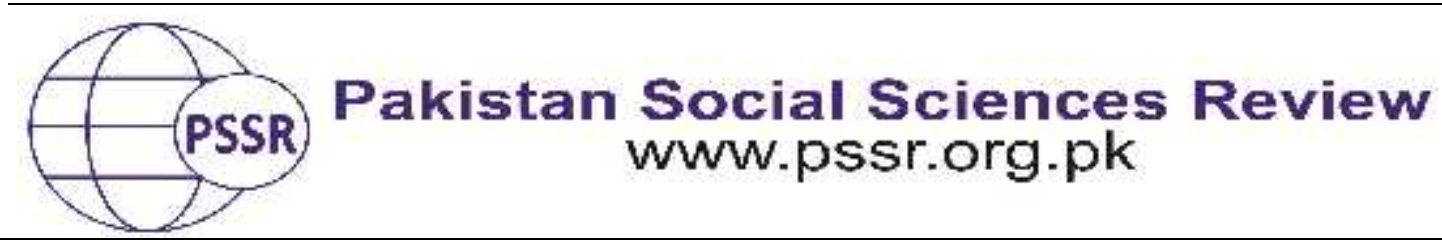

RESEARCH PAPER

\title{
US Media's Agenda-Setting: Analysis of Editorial Presentations of Pakistan
}

\author{
Dr. Samia Manzoor* ${ }^{1}$ Dr. Aqsa Iram Shahzadi ${ }^{2}$ Dr. Muhammad Ahsan Bhatti ${ }^{3}$
}

1. Assistant Professor, Department of Communication Studies, BZU, Multan, Punjab, Pakistan

2. Assistant Professor, Department of Communication Studies, BZU, Multan, Punjab, Pakistan

3. Assistant Professor, Department of Communication Studies, BZU, Multan, Punjab, Pakistan

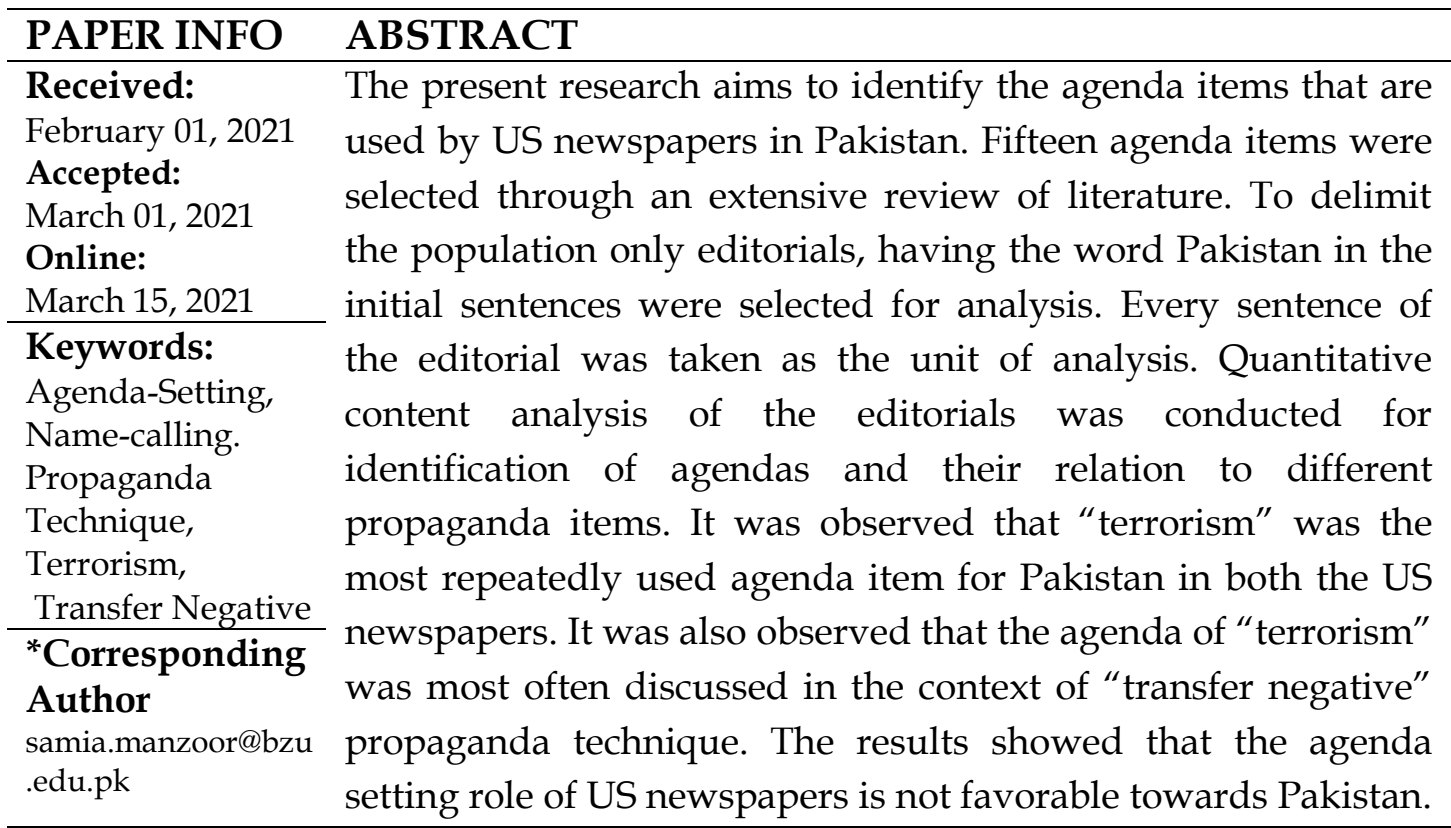

\section{Introduction}

An important aspect of the news media is that it takes an interest in some incidents and neglects others (Lowery and Defleur, 1995). Either the information given through the media is unbiased or not, choosy or not, but it definitely contributes a lot in making people aware about what is happening around them. But most press brings to attention only a limited number of topics which are considered important or about which press people want public to think. Walter Lippmann has already noted that people do not have many opportunities to have first hand information about many of the situations, so they are dependent on the press to get information about the latest events. And the press has a strong agenda-setting 
function. Lang and Lang (1966) write, "The mass media.............. are continuously giving matters, advising what people should ponder, know, and feel about" (p. 468).

It is obvious from the writings of Lasswell (1927), Berelson and Grazia (1947), Doob (1935), Schramm (1955), and Lee (1953) that how people perceive the significance of a message depends on the frequency of that message in the mass media. Lowery and Defleur (1995) argue that the issues which are presented prominently by the mass media are perceived importance by the masses and they rank and adopt them as very important. Fortunato and Martin (2016) claim that research through agenda-setting inspects the transfer of salience of issues from media to public.

Agenda-setting research has constantly presented propositions about how public agendas are developed. Because there is restricted space and time available in the media, different topics have to compete with each other to get placed in some media and gain public attention (Shaw \& Martin, 1992). The importance of issues or salience could be transferred (from media to the public) on the basis of selection.

Media not only set the agenda for the public, but also for other media organizations. The inter media agenda-setting is a very important function of mass media (McCombs \& Shaw, 1976; Golan, 2006; Lee, 2004). It means that issue salience gets transferred from one media to the other (White, 1950; Lopez-Escobar, Llamas, McCombs \& Lennon, 1998). The New York Times is considered very influential in this regard (Coleman et al, 2009). Reese and Danielian (1989) found that major news media not only influences but sometimes dictates the other media outlets (LopezEscobar et al, 1998). The present research aims to identify the agendas for Pakistan which were most repeatedly presented by US elite newspapers. This will help to gauge the agenda setting function of US media for Pakistan the public and for other media organizations.

\section{Literature Review}

Agenda-setting research has gone far beyond elections. Many scholars have explored agenda-setting of different issues, including unemployment, the nuclear issue, crime and poverty (Coleman et al., 2009). Wanta et al. (2004) took foreign countries as an object. They shifted the direction of agenda-setting research from its original area of public affairs to foreign countries. Previous research has found agenda-setting effect regarding international media and perception of public about other countries (McNelly\&Izcaray, 1986; Salwen\& Matera, 1992).

Iyengar and Simon (1993) commented that the media determines the public agenda by making some topics more salient than the others. Moreover, it was the press, which framed news in such a way that people supported a military rather diplomatic solution to the problem. Therefore, to study the role of media in doing propaganda, it is mandatory to address agenda-setting as well (Curnalia, 2005). 
Khan (2008) studied the image of Pakistan in American newspaper editorials. To investigate the presentation of Pakistan in the print media of a foreign country, he selected ten agenda categories including development, disasters, domestic politics, international politics, nuclear issue, Pak-India conflicts, including Kashmir, President General Pervez Musharraf, religion/Islamic movements/religious activities, war on terrorism, and others. He concluded that "war on terrorism" was the issue which received highest coverage in US elite newspaper editorials.

Siraj (2006) studied the image of Pakistan in American newspapers. He divided the coverage of Pakistan in nine different topics. Siraj defined topic as the essence of a news story because, topic covers key themes of a story (p. 29). It is clear from the definition of the topic by Siraj that he took "topic as agenda". The categories he developed to study the Pakistani image in the American press are the following: arts, culture, and society, development, foreign relations, Musharraf, PakIndia and Kashmir, Pakistan's internal politics, Pakistan nuclear, terrorism, and others. He found that Pak-India relations sought the most coverage followed by terrorism.

Manheim \&Albritton, (1984) pointed out that two aspects are very important to explore while analyzing a foreign country's image: visibility and valence. Visibility of a country is measured through first level agenda-setting where the frequency of coverage is measured. While valence is judged through second level agenda-setting and favorable or unfavorable framing of a country is analyzed (Zhang and Meadows III, 2012).

Semetko et al. (1992) conducted research to find out how a foreign country's visibility in US media affects US public opinion about that country. The researchers selected nine countries and analyzed their coverage in US media, over a period of six months followed by a nationwide survey. The results indicated that a significant association exists between how often a country is mentioned in the US media (visibility) and opinion of US citizens about these foreign countries.

Neuman et al (2014) explored big data to dig out the issues receiving attention in both traditional and social media during the year 2012. They divided the issues into six following areas: economics, environment, foreign affairs, public order, government, and social issues.

Sweetser and Brown (2010) conducted research on Iranian media to measure the attributes agenda-setting and framing in the communication made to international and national audience by the state controlled Iranian media. The agenda-setting attributes in Iranian propaganda were: enemy intimidates, good relationship with region, religion mention, only regional countries should provide security, enemy military assets/operations, enemy use of diplomacy, nuclear program is peaceful, historical mention, enemy arrests diplomats and Iran provides security in Gulf. These propaganda attributes were further divided into five themes or frames: enemy military, reasons for nuclear program, good neighbor, power, 
military power, and fear of enemy. The finding showed that Iran emphasized different attributes to different audiences. They concluded that Iran used a "forked tongue" (p. 238, 246) approach, making Iran's communication processes as complete propaganda.

Shah (2014) studied the depiction of Pakistan in The Daily Telegraph to assess the propaganda what this newspaper is doing against Pakistan. He categorized the content about Pakistan in four major categories on the basis of agendas this newspaper is presenting about Pakistan. These agendas were: terrorism, economy, politics and military of Pakistan. In the last category he placed all the other topics which The Daily Telegraph covered about Pakistan and named it "mix". Shah concluded that the overall coverage about Pakistan in The Daily Telegraph was negative. He analyzed 45 articles in total and more than half of the articles depicted a negative agenda about Pakistan. Most of the articles were about terrorism, Taliban, and religious extremism. The drone attacks were covered only once. Health, education, and other development topics were totally ignored. The author says that it is quite obvious that The Daily Telegraph is deliberately giving a negative picture of Pakistan.

Zhang and Meadows III (2012) conducted research by employing first and second- level agenda-setting theory to find out public perception about foreign countries formed through media agenda and policy agenda. They content analyzed The New York Times and presidential papers and surveyed the public. The results showed that there existed a strong correlation between media and public agenda regarding image of foreign countries.

Boulding (1969) clarifies many such elements which play a pivotal part in developing the national image of a country, for example, rapports and coalitions, conflicts and battles among nations, geographic space, strong points and weak points in the areas of political, economic and military. Hanan (2006) describes that favorable or unfavorable depiction of a nation in diplomatic, economic, historical, military, political, and religious way in the media determines its image in the public.

On the basis of the literature review, the researcher has identified fifteen different agenda items about Pakistan which will be identified in editorials of The New York Times and The Washington Post. These agendas are Terrorism, Nuclear issue, Religion/Religious activities, International community, Pakistan government/bureaucratic matters/officials, Domestic politics/politicians, Pak-India conflicts including Kashmir, Development, Disasters, Drone attacks, Islamist movements, General PervaizMusharraff, Asif Ali Zardari, Mian Mohammad Nawaz Sharif, Others.It was also observed that agenda-setting has never been studied in association with propaganda techniques in Pakistani context. So the present research has its vital importance to fill this important gap. Two research questions were formulated

RQ1: Is there any association between agendas and the newspapers (The New York Times and The Washington Post)? 
RQ2: What is the relationship of agendas presented by The New York Times and The Washington Post with propaganda techniques?

\section{Material and Methods}

Deductive content analysis has been considered a very suitable research technique to analyze agenda setting function of media. A literature review of the past media related researches revealed that researchers have used this technique very frequently to count the frequency of occurrence of media's agenda setting function (see Rai, Raya, Hajjar, \&Koshy, 2017; Lemke, 2018; Hingorjo \& Memon, 2018; Cushion, Kilby, Thomas, Morani \& Sambrook, 2018). A popular definition of content analysis is "a research technique for the objective, systematic, and quantitative description of the manifest content of communicative messages" (Berelson, 1952: as cited in Bryman, 2001). As the current research aimed to dig out the agenda items that are used by the editorialist's of The New York Times and The Washington Post, so content analysis was used as suitable research technique. It has also been established by experts that content analysis is usually considered a helpful technique to dig out messages which are meant widespread audiences and specifically for analysis of propaganda messages (Krippendorff, 2004). As the current research deals with a variety of variables so this technique was deliberated as the most suitable.

\section{Population}

Lexis-Nexis database was used to retrieve editorials which published in The New York Times and The Washington Post having "Pakistan" in the heading or in opening paragraph. The time period was post 9/11till 31 st December 2016. In total 274 editorial articles were identified, out of which 116 were found in The Washington Postwhile 158 were in The New York Times.All the articles identified in both the US newspapers were analyzed. No sample was selected rather a census was done. The whole editorial was analyzed to identify agenda. If more than one agenda was discussed in an editorial, weightage was given to the one which had been discussed with more frequency. While for the identification of propaganda techniques each sentence of the editorial was selected as unit of analysis.

\section{Agenda}

According to McCombs (2004), press is very powerful in America. It determines which topics will be discussed by the public; it regulates the agendas for public discourse. Agenda means a list of topics, items, or issues. So keeping in view the previously mentioned argument, it was find out that what issues were repeatedly given by The New York Times and The Washington Post, to their readers about Pakistan and what agendas did they follow in the editorials of these newspapers. Schramm and Atwood (1981) identified various categories that could be applied to analyze the treatment of a country in the media. After modifying a little Khan (2008), studied only ten categories instead of the fifteen presented by Schramm 
and Atwood (1981), to examine what angles of Pakistan are discussed and what image of Pakistan is trying to create in the American print media. Image categories developed by Khan (2008) were adapted in the present study to investigate the topics selected by The New York Times and The Washington Post about Pakistan only with minor additions and modifications in the titles. Following were the agenda categories which were studied in the present research.

1. Terrorism

2. Nuclear issue

3. Religion/Religious activities

4. International community

5. Domestic politics/politicians

6. Disasters

7. Development

8. Pak-India conflicts including Kashmir

9. Pakistan government/bureaucratic matters/officials

10. Drone attacks

11. Islamist movements

12. General PervaizMusharraff

13. Asif Ali Zardari

14. Mian Mohammad Nawaz Sharif

15. Others

\section{Propaganda Techniques}

In the current research the list of propaganda techniques identified by Institute of Propaganda Analysis (1939) is used to identify propaganda items.Frith (1983) said that Miller and Doob's seven propaganda techniques continue to give a succinct scope about the categories of propaganda "tricks" available in present-day US politics. Cunningham (2002) said that the techniques of propaganda which IPA (The Institute of Propaganda Analysis) identified in 1939 are classified as name calling, transfer, testimonial, glittering generalities, plain folks, bandwagon and card stacking. But these techniques have been modified a little by the researcher for better analysis. The propaganda techniques that were analyzed are

1. Name Calling

2. Glittering Generalities

3. Transfer positive

4. Transfer negative

5. Testimonial positive

6. Testimonial negative

7. Plain Folks

8. Bandwagon positive

9. Bandwagon negative

10. Other 
Card stacking is one of the propaganda technique identified by IPA. But the frequency count of this category is not possible (Conway, et al, 2007).So during the present study card stacking was not counted and analyzed as it is beyond the scope of this study

\section{Rationale for the Selection of Newspapers}

In the opinion of Dareier and Martin (2010) circulation-wise The New York Times and The Washington Postare top five American newspapers. The New York Times is said to have the second highest circulated newspaper in America and The Washington Post have the third highest. Moreover, Khan (2008) declares both of these as respected newspapers which are ranked as presenters of thoughtful journalism for the American people but are also acclaimed by international readers.

\section{Results and Discussion}

Table 1

Cross tabulation of agendas and newspapers

\begin{tabular}{|c|c|c|c|c|c|c|c|c|c|c|c|c|c|c|c|c|}
\hline \multicolumn{17}{|c|}{ Agenda } \\
\hline 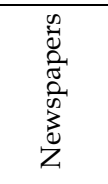 & 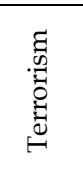 & 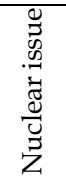 & 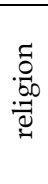 & 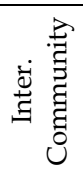 & 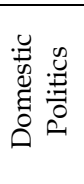 & 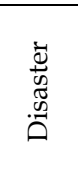 & 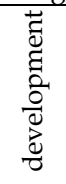 & 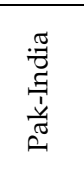 & 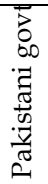 & 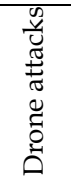 & 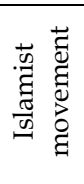 & 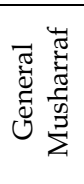 & $\begin{array}{l}\widetilde{\Xi} \\
\overline{\widetilde{J}} \\
\text { N }\end{array}$ & $\begin{array}{l}\text { N } \\
\text { క్ } \\
\text { Z }\end{array}$ & $\frac{\ddot{\Xi}}{\tilde{0}}$ & 元 \\
\hline TWP & 41 & 02 & 00 & 05 & 11 & 03 & 06 & 09 & 00 & 06 & 02 & 30 & 01 & 00 & 00 & $\begin{array}{c}11 \\
6\end{array}$ \\
\hline $\begin{array}{c}\text { Percent } \\
\text { age }\end{array}$ & $\begin{array}{c}35.34 \\
\%\end{array}$ & $\begin{array}{c}1.72 \\
\%\end{array}$ & $\begin{array}{l}0 \\
\%\end{array}$ & $\begin{array}{c}4.31 \\
\%\end{array}$ & $\begin{array}{c}9.48 \\
\%\end{array}$ & $\begin{array}{c}2.58 \\
\%\end{array}$ & $\begin{array}{c}5.17 \\
\%\end{array}$ & $\begin{array}{c}7.75 \\
\%\end{array}$ & $\begin{array}{l}0 \\
\%\end{array}$ & $\begin{array}{c}5.17 \\
\%\end{array}$ & $\begin{array}{c}1.72 \\
\%\end{array}$ & $\begin{array}{c}25.86 \\
\%\end{array}$ & $\begin{array}{c}0.86 \\
\%\end{array}$ & $0 \%$ & $0 \%$ & \\
\hline NYT & 27 & 09 & 00 & 18 & 18 & 25 & 04 & 21 & 00 & 04 & 00 & 26 & 00 & 01 & 05 & $\begin{array}{c}15 \\
8\end{array}$ \\
\hline $\begin{array}{l}\text { Percent } \\
\text { age }\end{array}$ & $\begin{array}{c}17.08 \\
\%\end{array}$ & $\begin{array}{c}5.69 \\
\%\end{array}$ & $\begin{array}{l}0 \\
\%\end{array}$ & $\begin{array}{c}11.39 \\
\%\end{array}$ & $\begin{array}{c}11.39 \\
\%\end{array}$ & $\begin{array}{c}15.82 \\
\%\end{array}$ & $\begin{array}{c}2.53 \\
\%\end{array}$ & $\begin{array}{c}13.29 \\
\%\end{array}$ & $\begin{array}{l}0 \\
\%\end{array}$ & $\begin{array}{c}2.53 \\
\%\end{array}$ & $0 \%$ & $\begin{array}{c}16.45 \\
\%\end{array}$ & $0 \%$ & $\begin{array}{c}0.63 \\
\%\end{array}$ & $\begin{array}{c}3.16 \\
\%\end{array}$ & \\
\hline Total & 68 & 11 & 00 & 23 & 29 & 28 & 10 & 30 & 00 & 10 & 02 & 56 & 01 & 01 & 05 & $\begin{array}{r}27 \\
4\end{array}$ \\
\hline $\begin{array}{l}\text { Percent } \\
\text { age }\end{array}$ & $\begin{array}{c}24.81 \\
\%\end{array}$ & $\begin{array}{c}4.01 \\
\%\end{array}$ & $\begin{array}{c}0 \\
\%\end{array}$ & $\begin{array}{c}8.39 \\
\%\end{array}$ & $\begin{array}{c}10.58 \\
\%\end{array}$ & $\begin{array}{c}10.21 \\
\%\end{array}$ & $\begin{array}{c}3.64 \\
\%\end{array}$ & $\begin{array}{c}10.94 \\
\%\end{array}$ & $\begin{array}{l}0 \\
\%\end{array}$ & $\begin{array}{c}3.64 \\
\%\end{array}$ & $\begin{array}{c}0.72 \\
\%\end{array}$ & $\begin{array}{c}20.43 \\
\%\end{array}$ & $\begin{array}{c}0.36 \\
\%\end{array}$ & $\begin{array}{c}0.36 \\
\%\end{array}$ & $\begin{array}{c}1.82 \\
\%\end{array}$ & \\
\hline
\end{tabular}

Pearson Chi-Square $=43.121, \mathrm{df}=12, \mathrm{p}$-value $=0.000$

Chi-square test was applied to check the association between and newspaper and agenda, the value of Chi-Square is 43.121 and its P-value is 0.000 which shows a statistically significant association. It means an association exists between newspapers and the agendas they are presenting about Pakistan. The agendas of "terrorism", "General Pervez Musharraf" and "domestic politics" are the most abundant in The Washington Post while The New York Times is giving most of the coverage to the agendas of "terrorism", "General Pervez Musharraf" and "Pak-India Conflict". 
Table 2

Descriptive statistics of agendas and propaganda techniques

\begin{tabular}{|c|c|c|c|c|c|c|}
\hline \multicolumn{7}{|c|}{ Descriptive Statistics } \\
\hline & Agenda & $\mathbf{N}$ & Minimum & Maximum & Mean & Std. Deviation \\
\hline \multirow{7}{*}{ Terrorism } & Transfer Positive & 68 & .00 & 18.00 & 2.1618 & 3.06453 \\
\hline & Transfer Negative & 68 & .00 & 30.00 & 9.6324 & 8.07041 \\
\hline & TestiPositive & 68 & .00 & 3.00 & .1324 & .45398 \\
\hline & TestiNegative & 68 & .00 & 4.00 & .5147 & 1.07193 \\
\hline & Glittering Generalities & 68 & .00 & 3.00 & .2353 & .62576 \\
\hline & Name Calling & 68 & .00 & 9.00 & 3.0000 & 2.72084 \\
\hline & Valid N (listwise) & 68 & & & & \\
\hline \multirow{7}{*}{ Nuclear issue } & Transfer Positive & 11 & .00 & 5.00 & .8182 & 1.53741 \\
\hline & Transfer Negative & 11 & 1.00 & 27.00 & 13.0000 & 7.68115 \\
\hline & TestiPositive & 11 & .00 & 2.00 & .1818 & .60302 \\
\hline & TestiNegative & 11 & .00 & 1.00 & .0909 & .30151 \\
\hline & GlitteringGeneralities & 11 & .00 & 1.00 & .1818 & .40452 \\
\hline & NameCalling & 11 & .00 & 5.00 & 2.6364 & 2.06265 \\
\hline & Valid N (listwise) & 11 & & & & \\
\hline \multirow{7}{*}{$\begin{array}{l}\text { International } \\
\text { community }\end{array}$} & Transfer Positive & 23 & .00 & 10.00 & 1.9130 & 2.85901 \\
\hline & Transfer Negative & 23 & .00 & 26.00 & 9.8261 & 6.95212 \\
\hline & TestiPositive & 23 & .00 & 1.00 & .0435 & .20851 \\
\hline & TestiNegative & 23 & .00 & 1.00 & .0435 & .20851 \\
\hline & GlitteringGeneralities & 23 & .00 & 1.00 & .2174 & .42174 \\
\hline & NameCalling & 23 & .00 & 11.00 & 2.4783 & 2.53825 \\
\hline & Valid N (listwise) & 23 & & & & \\
\hline \multirow{7}{*}{$\begin{array}{l}\text { Domestic } \\
\text { politics }\end{array}$} & Transfer Positive & 29 & .00 & 18.00 & 3.2759 & 4.04348 \\
\hline & Transfer Negative & 29 & 2.00 & 31.00 & 14.2759 & 7.25011 \\
\hline & TestiPositive & 29 & .00 & 1.00 & .0690 & .25788 \\
\hline & TestiNegative & 29 & .00 & 4.00 & .5172 & 1.08958 \\
\hline & GlitteringGeneralities & 29 & .00 & 7.00 & .9310 & 1.70987 \\
\hline & NameCalling & 29 & .00 & 10.00 & 3.3793 & 2.69144 \\
\hline & Valid N (listwise) & 29 & & & & \\
\hline \multirow{7}{*}{ Disaster } & Transfer Positive & 28 & .00 & 12.00 & 2.3571 & 2.88308 \\
\hline & Transfer Negative & 28 & .00 & 25.00 & 10.4286 & 7.47553 \\
\hline & TestiPositive & 28 & .00 & 7.00 & .4286 & 1.37244 \\
\hline & TestiNegative & 28 & .00 & 4.00 & .4643 & .99934 \\
\hline & GlitteringGeneralities & 28 & .00 & 3.00 & .4643 & .96156 \\
\hline & NameCalling & 28 & .00 & 5.00 & 1.0714 & 1.38587 \\
\hline & Valid N (listwise) & 28 & & & & \\
\hline \multirow{7}{*}{ Development } & Transfer Positive & 10 & .00 & 13.00 & 3.5000 & 4.11636 \\
\hline & Transfer Negative & 10 & 1.00 & 11.00 & 4.4000 & 3.65756 \\
\hline & TestiPositive & 10 & .00 & 3.00 & .3000 & .94868 \\
\hline & TestiNegative & 10 & .00 & 4.00 & .4000 & 1.26491 \\
\hline & GlitteringGeneralities & 10 & .00 & 3.00 & .5000 & 1.08012 \\
\hline & NameCalling & 10 & .00 & 7.00 & 1.5000 & 2.46080 \\
\hline & Valid N (listwise) & 10 & & & & \\
\hline \multirow{7}{*}{$\begin{array}{l}\text { Pak India } \\
\text { conflict }\end{array}$} & Transfer Positive & 30 & .00 & 17.00 & 3.0333 & 3.99554 \\
\hline & Transfer Negative & 30 & .00 & 19.00 & 7.2667 & 4.79895 \\
\hline & TestiPositive & 30 & .00 & 2.00 & .1667 & .53067 \\
\hline & TestiNegative & 30 & .00 & 1.00 & .0333 & .18257 \\
\hline & GlitteringGeneralities & 30 & .00 & 2.00 & .2000 & .48423 \\
\hline & NameCalling & 30 & .00 & 6.00 & 1.8667 & 1.63440 \\
\hline & Valid N (listwise) & 30 & & & & \\
\hline \multirow{7}{*}{ Drone attacks } & Transfer Positive & 10 & .00 & 3.00 & .8000 & 1.13529 \\
\hline & Transfer Negative & 10 & .00 & 11.00 & 2.5000 & 3.20590 \\
\hline & TestiPositive & 10 & .00 & .00 & .0000 & .00000 \\
\hline & TestiNegative & 10 & .00 & 2.00 & .2000 & .63246 \\
\hline & GlitteringGeneralities & 10 & .00 & 2.00 & .5000 & .70711 \\
\hline & NameCalling & 10 & .00 & 2.00 & .9000 & .99443 \\
\hline & Valid N (listwise) & 10 & & & & \\
\hline
\end{tabular}




\begin{tabular}{|c|c|c|c|c|c|c|}
\hline \multirow{7}{*}{$\begin{array}{c}\text { Islamist } \\
\text { movement }\end{array}$} & Transfer Positive & 2 & .00 & 1.00 & .5000 & .70711 \\
\hline & Transfer Negative & 2 & .00 & 13.00 & 6.5000 & 9.19239 \\
\hline & TestiPositive & 2 & .00 & 2.00 & 1.0000 & 1.41421 \\
\hline & TestiNegative & 2 & .00 & 1.00 & .5000 & .70711 \\
\hline & GlitteringGeneralities & 2 & .00 & .00 & .0000 & .00000 \\
\hline & NameCalling & 2 & 2.00 & 7.00 & 4.5000 & 3.53553 \\
\hline & Valid N (listwise) & 2 & & & & \\
\hline \multirow{7}{*}{$\begin{array}{c}\text { General } \\
\text { Musharraf }\end{array}$} & Transfer Positive & 56 & .00 & 12.00 & 2.3036 & 2.48574 \\
\hline & Transfer Negative & 56 & 1.00 & 33.00 & 15.1429 & 7.97366 \\
\hline & TestiPositive & 56 & .00 & 5.00 & .3571 & 1.03447 \\
\hline & TestiNegative & 56 & .00 & 4.00 & .3750 & .92564 \\
\hline & GlitteringGeneralities & 56 & .00 & 6.00 & .7321 & 1.34152 \\
\hline & NameCalling & 56 & .00 & 13.00 & 3.3750 & 2.94534 \\
\hline & Valid N (listwise) & 56 & & & & \\
\hline \multirow{7}{*}{ Zardari } & Transfer Positive & 1 & 1.00 & 1.00 & 1.0000 & . \\
\hline & Transfer Negative & 1 & 12.00 & 12.00 & 12.0000 & . \\
\hline & TestiPositive & 1 & .00 & .00 & .0000 & . \\
\hline & TestiNegative & 1 & 1.00 & 1.00 & 1.0000 & . \\
\hline & GlitteringGeneralities & 1 & 2.00 & 2.00 & 2.0000 & . \\
\hline & NameCalling & 1 & 3.00 & 3.00 & 3.0000 & . \\
\hline & Valid N (listwise) & 1 & & & & \\
\hline \multirow{7}{*}{ Nawaz } & Transfer Positive & 1 & 12.00 & 12.00 & 12.0000 & . \\
\hline & Transfer Negative & 1 & 9.00 & 9.00 & 9.0000 & . \\
\hline & TestiPositive & 1 & .00 & .00 & .0000 & . \\
\hline & TestiNegative & 1 & .00 & .00 & .0000 & . \\
\hline & GlitteringGeneralities & 1 & 1.00 & 1.00 & 1.0000 & . \\
\hline & NameCalling & 1 & 1.00 & 1.00 & 1.0000 & . \\
\hline & Valid N (listwise) & 1 & & & & \\
\hline \multirow{7}{*}{ Other } & Transfer Positive & 5 & .00 & 1.00 & .2000 & .44721 \\
\hline & Transfer Negative & 5 & .00 & 5.00 & 1.6000 & 1.94936 \\
\hline & TestiPositive & 5 & .00 & .00 & .0000 & .00000 \\
\hline & TestiNegative & 5 & .00 & .00 & .0000 & .00000 \\
\hline & GlitteringGeneralities & 5 & .00 & .00 & .0000 & .00000 \\
\hline & NameCalling & 5 & .00 & 1.00 & .2000 & .44721 \\
\hline & Valid N (listwise) & 5 & & & & \\
\hline
\end{tabular}

The data showed that out of ten propaganda techniques only six were present in the editorial articles of The Washington Post and The New York Times. In the table 4.2, relation between agenda items and propaganda techniques is demonstrated. The table showed that six propaganda techniques were used but the most repeatedly visible technique was" transfer negative" under the agenda of "terrorism" having a mean score of $9.6(S D=8.07)$, followed by name calling with mean of $3.00(S D=2.72)$. Transfer negative again remained the most frequently occurring propaganda technique under the agenda of "nuclear issue" having a mean score of $13.00(S D=7.68)$, followed by name calling with mean of $2.63(S D=2.06)$. It once again received the most coverage under the agenda of "international community" showing a mean score of $9.82(S D=6.95)$, followed by name calling with mean of $2.47(S D=2.53)$. The agenda of "domestic politics" had no exception where Transfer negative remained highest among the other propaganda techniques, with a mean score of 14.27 ( $S D=7.25)$, followed by name calling with mean of 3.37 $(S D=2.69)$. It was the again most frequently occurring propaganda technique under the agenda of "disaster" with a mean score of $10.42(S D=7.47)$, followed by transfer positive with mean of $2.35(S D=2.88)$, placing name calling with mean of 1.07 (SD 
$=1.3$ ) at number three. Under the agenda of "development" transfer negative had a mean score of $4.40(S D=3.65)$, followed by transfer positive with mean of $3.50(S D=$ 4.11) placing name calling with mean of $1.5(S D=2.4)$ at number three. Transfer negative appeared at most of instances under the agenda of "Pak India conflict" with a mean score of $7.26(S D=4.79)$, followed by transfer positive with mean of 3.03 (SD $=3.99)$ placing name calling with mean of $1.86(S D=1.63)$ at number three. Evenunder the agenda of "drone attacks" transfer negative was the most frequent technique with a mean score of $2.50(S D=3.20)$, followed by name calling with mean of $.90(S D=.99)$. Transfer negative was the most frequently occurring propaganda technique under the agenda of "Islamist movements" with a mean score of 6.50 (SD $=9.19)$, followed by name calling with mean of $4.50(S D=3.53)$. Transfer negative was the most frequently occurring propaganda technique under the agenda of "General Pervez Musharraf" with a mean score of 15.14 (SD = 7.0), followed by name calling with mean of $3.37(S D=2.94)$. Transfer negative was the most frequently occurring technique under the agenda of "Asif Ali Zardari" with a mean score of $12.00(N=1)$, followed by name calling with mean of $3.00(N=1)$. Transfer positive remained the most frequently occurring propaganda technique under the agenda of "Mian Muhammad Nawaz Shareef" with a mean score of 12.00, no standard deviation was observed because of $(N=1)$, followed by transfer negative with mean of $9.00(N=1)$ placing name calling with mean of $1.00(N=1)$ at number three. Transfer negative was the most frequently occurring propaganda technique under the agenda of "other" with a mean score of $1.60(S D=1.94)$, followed by simultaneously name calling and transfer positive with mean of $.20(S D=.447)$.

\section{Conclusion}

The researchers formulated two research questions to gauge through the present research. The first research question was to identify that, is there any association between agendas and the newspapers (The New York Times and The Washington Post). Quantitative content analysis was conducted to find out the instances of agenda items in both the newspapers. The results showed that both the newspapers are most frequently using the agenda of "terrorism" to discuss Pakistan. The results are concurred with the results of Khan (2008) and Shah (2014). Pakistan has remained a very significant US ally in the war against terrorism (Kronstadt, 2012). So it was assumed that Pakistan must be discussed in a positive light by US newspapers. But the results were contrary to this notion. To find out the attitude of US media towards Pakistan, which they adopted while discussing Pakistan, a second research question was formulated.

The second RQ was about the relationship of agendas presented by The New York Times and The Washington Post with propaganda techniques. The data showed that "transfer negative" appeared most frequently with all the agendas except the agenda of "Mian Muhammad Nawaz Shareef". Transfer negative is a propaganda technique that "means taking a position derogatory and disrespectful, one person or idea and transferring it to another person or idea to make it appear disrespectful. Transfer negative was considered when negativity and disrespectfulness of something was related with Pakistan, Pakistani nationals (either elites or common 
people), Pakistan army, Pakistani officials or any other thing which is Pakistani even ideas, ideologies, beliefs and brands etc." It means that Pakistan whenever was discussed under the agenda of "terrorism" it received negative or disrespectful coverage. Ali, Jan and Ahmed (2013) identified that the US media even called Pakistan "safe haven for terrorists". Transfer negative was usually followed by "name calling". Name-calling means giving a malicious or evil name to anotion or individual. Presenting a notion/individual in such damagingexpressions that public will castoff or admit it at once without bearing in mind its honesty. Manzoor and Khan (2019) defined "name calling", as"if derogatory terms/words (e.g. supporting Taliban, liar, terrorist supporter) will be used for Pakistan, Pakistani nationals (either elites or common people), Pakistan army, Pakistani officials or any other thing which is Pakistani even ideas, ideologies, beliefs and brands etc. Moreover if good terms are used for bad things or bad people and are then associated in a sarcastic manner with Pakistan, Pakistani nationals (either elites or common people), Pakistan army, Pakistani officials or any other thing which is Pakistani even ideas, ideologies, beliefs and brands etc., it was also considered as name calling (e.g. corrupt politician, Mr. ten percent)". The concept of "name calling" clarifies it that it is an extremely negative propaganda technique. Whenever it was used for Pakistan, it painted an exceptionally negative picture of Pakistan.

It was also identified that transfer negative propaganda technique remained the most abundant with the agenda of "General Pervez Musharraf". It means that the highest number of transfer negative was used with the agenda of "General Pervez Musharraf".These results are congruent with the results of Yousaf, Ali, \& Ahmed (2013). Name calling remained highest during the agenda of "Islamist movements". While transfer positive remained most frequent with the agenda of "Mian Muhammad Nawaz Shareef" with a mean score of 12.00.

The present research concludes that US media presented Pakistan in a very negative and unfavorable way. Though Pakistani government mostly helped US government during war on terror, but US media did not treated Pakistan well. As written by Markey (2013) that after a decade of 9/11 relations between Pakistan and US were as bad as they were before Musharraf indulged in the war on terror initiated by Bush. This statement of Markey shows that Pakistan had good relations with US during war on terror but the media treatment of Pakistan does not endorse this impression. Pakistan usually had troubled relationship with US (Kronstadt, 2011). And US media presentation of Pakistan shows that they put all the blame on Pakistan for this "troubled relationship". A very giganticpoint of concern for Pakistani government here is that US media performs inter media agenda setting function as well (Coleman et al, 2009), so if one influential media outlet presents negative image of Pakistan it triggers many others to follow suit.Pakistani government must take concrete measures to counter this kind of foreign media agenda-setting and propaganda. 


\section{References}

Ali, Z., Iqbal, A., Jan, M., \& Ahmad, A. (2013).Coverage of Pak-US Relations on Issue of Counter Terrorism by US Leading News Magazines. Middle-East Journal of Scientific Research, 15(10), 1464-1471.

Berelson, B., \& De Grazia, S. (1947). Detecting collaboration in propaganda. Public Opinion Quarterly, 11(2), 244-253.

Carroll, C.E. \& McCombs, M. (2003).Agenda-setting effects of business news on the public's images and opinions about major corporations, Corporate Reputation Review, 16, 36-46.

Chevrov, G., Valenzuela, S. \& McCombs, M. E. (2011).An experimental comparison of two perspectives on the concept of the need for orientation in agenda-setting theory.Journalism and Mass Communication Quarterly, 88(1), 142-155.

Coleman, R., McCombs, M., Shaw, D., \& Weaver, D. (2009). Agenda Setting. In K. W. Jargensen\& T. Hanitzsch. (Eds.) The Handbook of Journalism Studies. (pp. 147-160). New York, NY: Routledge

Curnalia, R. M.L.(2005). A Retrospective on Early Studies of Propaganda and Suggestions for Reviving the Paradigm, Review of Communication, 5(4): 237-257. DOI: $10.1080 / 15358590500420621$.

Cushion, S., Kilby, A., Thomas, A., Morani, M. \& Sambrook, R. (2018). Newspapers, Impartiality and Television News, Journalism Studies, 19(2), 162-181, DOI: 10.1080/1461670X.2016.1171163

Doob, L. W. (1935). Propaganda: Its Psychoilogy and Techniques. New York: Holt.

Fortunato, J., \& Martin, S. (2016). The Intersection of Agenda-Setting, the Media Environment, and Election Campaign Laws. Journal of Information Policy, 6, 129153.

Golan, G. (2006). Inter-media agenda-setting and global news coverage: Assesing the influence of the New York Times on three network television evening programs. Journalism Studies, 7(2), 323-333. DOI: 10.1080/14616700500533643.

Hingorjo, A. A. \&Memon, B. A. (2018). Environmental Problems of the Indus Delta in Pakistani Print Media: An Agenda Setting Analysis, Grassroots, 52(11), 96-110,

Jeslyn, L. (2018). Setting the Agenda on Development: A Content Analysis of How Senegalese Newspapers Report on Local and Foreign Aid, African Journalism Studies, 39(2), 61-74, DOI: $\underline{10.1080 / 23743670.2018 .1473268}$

Kronstadt, K. A. (2011, October). Pakistan-US relations: A summary. Library of Congress, Congressional Research Service. 
Kronstadt, K. A. (2012). Pakistan-US relations. Washington, DC: Congressional Research Service.

Lang, K\& Lang, G. E. (1966).The Mass Media and Voting.In B. Berelson\& M. Janowitz, (Eds.).Reader in Public Opinion and Communication.(2nd Edition). NY: Free Press.

Lasswell, H. D. (1927a). Propaganda Techniques in the World War. New York: Smith.

Lee, A. M. (1953). How to Understand Propaganda? New York: Rinehard\& Company.

Lee, G. (2004). Do you mirror me? Inter-media agenda-setting effects among online media in Korea. Paper presented to the International Communication Division at the annual convention of the Association for Education in Journalism and Mass Communication, Toronto, Canada.

Lopez-Escobar, E., Llamas, J. P., McCombs, M., \&Lennon,F. R. (1998). Two levels of inter-media agenda-setting among advertising and news agenda in the 1995 Spanish regional elections. Political Communication, 15, 225-238.

Lowery, S. A. \& DeFleur, M. L. (1995).Milestones in Mass Communication Research.Media Effects.(3rd Edition). White Plains, NY: Longman.

Manzoor, S., \& Khan, M. A. (2019). Presentation of Pakistani Political Regimes in the Editorials of The Washington Post and The New York Times: An Empirical Investigation of Propaganda Techniques and Media Frames. Pakistan Journal of Social Sciences (PJSS), 39(3), 1175 - 1185.

Markey, D. S. (2013). No exit from Pakistan: America's tortured relationship with Islamabad. Cambridge University Press.

McCombs, M. E. \& Shaw, D. L. (1976). Structuring the "unseen environment." Journal of Communication, 2, 18-22.

Rai, A. Ashok., Raya, R., Hajjar, M. \&Koshy, S. (2017), Public opinion and Agenda Setting in the UAE National News: A quantitative content analysis, Humanities and Social Sciences Review, 7(1), 273-286.

Reese, S. D., Danielian, L. H. (1989). A closer look at inter-media influences on agenda setting: the cocaine issue of 1986. In P. J. Shoemaker (Ed.) Communication campaigns about drugs: government, media and the public (47-66). Hillsdale, NJ: Lawrence Erlbaum

Schramm, W. (1955b). The Soviet Concept of "Psychological" Warfare.In (unknown Eds.)Four Working Papers on Propaganda Theory, 101-145. Columbus, OH: Ohio State University. 
Shaw, D., \& Martin, S. (1992). The function of mass media agenda setting.Journalism Quarterly, 69, 902-920.

Wanta, W. and $\mathrm{Wu}, \mathrm{Y}$. (1992).Interpersonal communication and the agenda-setting process.Journalism Quarterly, 69(4), 847-855.

Weaver, D. (1980). Audience need for orientation and media effects. Communication Research, 7(3), 361-376.

White, D. M. (1950). The "gate-keeper": A case study in the selection of news. Journalism Quarterly, 27(3), 383-390.

Yousaf, Z., Ali, E., \& Ahmed, M. (2013). Media \& Foreign Policy: Portrayal of Pak-US Relations in Elite Press during Pervaiz Musharraf \& George W. Bush Regime; September 2001 to August 2008. International Journal of Physical and Social Sciences, 3(2), 158-173.

Zhu, J. H., James H. Watt, J. H., Snyder, L. B., Yan, J. and Jiang, Y. (1993). Public Issue Priority Formation: Media Agenda-Setting and Social Interaction. Journal of Communication 43(1), 8-29. 